\title{
Microalgae Based Sustainable Bioremediation of Water Contaminated by Pesticides
}

\author{
Muskan Singhal ${ }^{1(\mathbb{D})}$, Swapnali Jadhav ${ }^{2(\mathbb{D})}$, Swaroop S. Sonone ${ }^{2(\mathbb{D})}$, Mahipal Singh Sankhla ${ }^{3 * * \mathbb{D}}$, Rajeev \\ Kumar $^{4}$ iD \\ 1 Department of Forensic Science, Vivekanand Global University, Jaipur, Rajasthan, India; \\ muskansinghal2013@gmail.com (M.S.); \\ 2 Government Institute of Forensic Science, Aurangabad, Maharashtra, India; jadhavswapnali6760@gmail.com (S.J.); \\ sononeswap4@gmail.com (S.S.S.); \\ 3 Department of Forensic Science, Institute of Sciences, SAGE University, Indore, Madhya Pradesh, India; \\ mahipa14n6@gmail.com (M.S.S.); \\ 4 Department of Forensic Science, School of Basic and Applied Sciences, Galgotias University, Greater Noida, U.P., India; \\ rajeev4n6@gmail.com (R.K.); \\ * Correspondence: mahipal4n6@gmail.com;
}

Scopus Author ID 57219964786

Received: 28.02.2021; Revised: 2.04.2021; Accepted: 5.04.2021; Published: 19.04.2021

\begin{abstract}
The use of pesticides in agriculture reduces the loss of crops and increases crop productivity. Agricultural discharge into water bodies increases pesticide toxicity in water. A pesticide, when entered into water bodies, attacks non-targeting species, which disturbs the aquatic life. Because of low-cost taking, high material removal efficiency, low sludgy amount, and generated biomass for economic benefit, biological bioremediation methods are mostly preferred. Algae are used to remove pollutants from the environment or to convert them into harmless forms. Bioremediation by algae is highly preferred as biomass generated is used in biogas and biofuel production. Algae fix carbon dioxide $\left(\mathrm{CO}_{2}\right)$ and release oxygen $\left(\mathrm{O}_{2}\right)$ by photosynthesis and increase BOD (biological oxygen demand) in contaminated water. Therefore, it is necessary to reduce the use of pesticides or dispose of them in the best manner. To be on the safer side and make our water bodies less toxic, it is necessary to make efficient water treatment arrangements. This review paper is to discuss everything about pesticides and bioremediation, the use of microalgae and fungi for the treatment of water contaminated by pesticides, and the factors affecting pesticide bioremediation.
\end{abstract}

Keywords: bioremediation; microalgae; fungi; pesticide; phytoremediation.

(C) 2021 by the authors. This article is an open-access article distributed under the terms and conditions of the Creative Commons Attribution (CC BY) license (https://creativecommons.org/licenses/by/4.0/).

\section{Introduction}

Water is one of the essential commodities on earth. $71 \%$ of the earth is made up of water, out of which $97 \%$ is marine water and the rest $3 \%$ is freshwater. The largest amount of freshwater consumption is done by the agricultural sector, but chemicals such as pesticides, agrochemicals, sediments, organic matter, drug residues and fertilizers used in agriculture to increase crop productivity are very harmful to both surface water and underground water [1, 2]. Out of several discharges that go into water bodies, agricultural discharge is considered the most harmful. The increasing population results in the usage of contaminated water at both industrial and agricultural levels. Contaminated water is vulnerable to animals and human beings, resulting in several diseases like diarrhea, cholera, dysentery, typhoid, and polio [3]. A highly infected contaminate in water bodies is a pesticide. Pesticides are the chemical 
compounds used by the agricultural sector to increase crop productivity. But when pesticide goes into a water body, it serves as a toxic agent [4]. An ecosystem tends to dilute some pollutants itself, but high contamination in the aquatic ecosystem results in alteration of flora and fauna. Even a very minute quantity of pesticide can be lethal. Toxicity depends on the exposure time. As biomagnifications of lethal pesticides in water result in the loss of biodiversity, animals, plants, and microbes, proper water treatment is necessary [5]. There are physical (adsorption, UV-radiation, membrane filtration), chemical (ionization, oxidation), conventional (sedimentation, nitrification, denitrification), and biological methods for water treatment [6-9]. Generally, contaminated water is separated from holy rivers by simply taking off the garbage, but it leaves several other contaminants in the water body. Moreover, physical and chemical methods are not considered or preferred as these methods have low removal efficiency, leave a high mass of sludge, need extra efforts to decompose sludge, require high energy input, and are time-consuming processes [10-15]. Therefore, bioremediation techniques (techniques that use microbes) are considered safe and sustainable methods to remove toxicants from contaminated water. The most important factor for this process to occur is the availability of contaminants for microbes or their enzymes so that the metabolism of contaminants can occur [3]. The process of bioremediation uses different microbes such as bacteria, algae, fungi, and yeast to treat oil spills, contaminated soil, contaminated water, and many more. The microbes' selection depends on the contaminated area because every microbe needs different $\mathrm{pH}$, temperature, and moisture for its activation. Microbes used in this process are also called bioremediators [16]. This process can be carried out easily without disturbing human lives and the environment during conduction and transportation. In algae-based bioremediation, algae fix carbon dioxide and release oxygen by photosynthesis and increase biological oxygen demand in contaminated water [16]. It is highly adaptive, i.e., it can grow autotrophically, heterotrophically, or mixotrophically in the environment. Algae absorb nutrients like carbon, phosphate, heavy metals from wastewater and produce new biomass, which is useful in the generation of bioenergy [17]. Due to the major presence of a concentration of inorganic phase, cultivation and extraction can be done under very mild conditions. Since contamination is unevenly distributed all over water life, several other approaches such as composting and bioaugmentation are used to perform several other bioremediation methods depending on their performance rate in that particular area [18]. Preservation of quality water should be a matter of consent for everyone. Therefore, proper techniques and water treatment plans should be taken under observation to save both underwater life and living lives.

\section{Pesticides}

Pesticides are the substance used to kill external features which tend to destroy the crop. Due to the high accumulative characteristic (tendency to increase amount) and persistency (tendency to stay for a long time), pesticides reduce loss in crop and increases crop productivity which is highly beneficial for farmers [19]. The high rate of pesticide production results in a high benefit to the agricultural sector. As the increasing population demands more food and to meet them, the uses of pesticides were introduced. Data suggests that rice production (which feeds more than fifty percent of the population) has increased three times by the use of pesticides, and wheat production has increased by nearly 160 percent [20]. As pesticides help farmers to grow more crops on less land, therefore it helps to limit deforestation. But hazardous effects of the pesticide cannot be ignored, and most of them are toxic. If not treated properly 
and effectively, they can contaminate soil, water, kill wildlife, etc. Some of the shortcomings that make pesticides more toxic are [21-24]. Surface runoff from previously contaminated land. Improper storage and transport of pesticides. Spraying pesticides improperly. Improper disposal of pesticide-contaminated waste from industries. This is highly dangerous to human as well as aquatic life. Runoff from farms containing pesticides in rivers, lakes, oceans results in high risks to several resident species [25, 26]. An effective remediation technique should be developed to deal with the harmful effects of pesticides. Therefore it is high time to remove pesticides from water bodies by sustainable methods like bioremediation. Sustainable treatment will not affect underwater as well on the land ecosystem.

\subsection{Types of pesticides.}

Pesticides are classified into 4 categories depending upon their chemical composition: organochlorines, organophosphorus, carbamate, pyrethrin, and pyrethroid [27]. Depending on the structure, organochlorines are divided into five classes [28], which are depicted in Figure 1. Asorganophosphate pesticides are the esters derived from phosphoric acid. Some organic ester compounds derived from dimethyl N-methyl carbamic acid are used as herbicides, insecticides, nematicides, and fungicides, and named carbamates. The toxicity of carbamate compounds varies according to the molecular structure, but they have a shorter duration compared to organophosphates and organochlorines, and the latter inhibits acetylcholinesterase $[29,30]$. Pyrethroids are natural insecticides derived from the pyrethrum extracts of chrysanthemum flowers known as pyrethrin found in Kenya. By duplicating the structure of natural pyrethrins, Synthetic pyrethroid pesticides can be synthesized, which is the group of organic pesticides. Mostly used synthetic pyrethroid pesticides are Cypermethrin and Permethrin [31]. Pesticides worldwide are divided into different categories according to their target organisms, and pesticides are given specific names to reflect their action. Some of these categories include herbs, pesticides, fungicides, rodenticides, molluscicides, nematicides, and plant growth regulators. Uncontrolled use of pesticides has had a devastating effect on the environment. Excessive use of pesticides has raised serious concerns about human health and biodiversity [32,33].

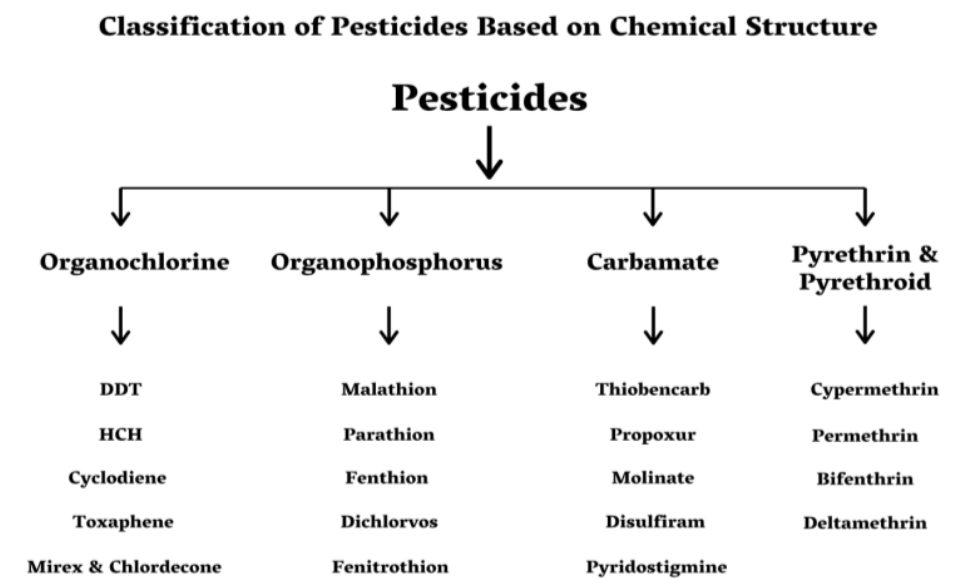

Figure 1. Classification of pesticides based on the chemical structures. 


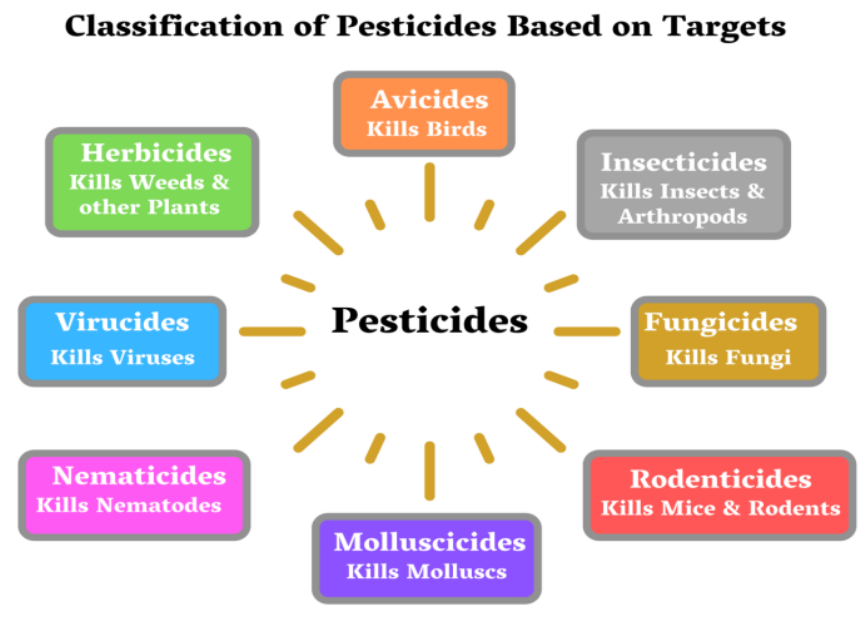

Figure 2. Classification of pesticides based on the targets.

\subsection{Routes of pesticide exposure to humans.}

Pesticides can enter the human body in many ways. It can directly enter from occupational, agricultural, and household use, while it can also be transferred indirectly through our diet. Moreover, there are many ways by which the general population may be exposed to pesticides due to their application on golf courses, around major roads, etc. Food chain, air, water, soil, flora, and fauna are the major routes of human exposure to pesticides [34]. There are many sources where drinking water comes from, including surface water and groundwater as well as public water and private wells. Due to these factors and the incomplete amount of information available, estimates of the risk of pesticides from water intake and the health effects of that exposure are currently unavailable [35]. One of the most common and effective routes through which pesticide applicators are exposed to pesticides is dermal exposure [34]. It may occur due to a splash, spill, or spray drift when mixing, loading, disposing, and/or cleaning pesticides [36]. The most severe poisoning may result when a pesticide is introduced through oral exposure. Oral exposure to a pesticide usually occurs due to accidents because of carelessness or intentional reasons [37]. The most frequent accidental oral exposure cases were reported to occur when pesticides were transferred from their original labeled container to an unlabeled bottle or food container [38]. The potential for chemical injury is high for tissues of the eye. Some pesticides were reported to be absorbed by the eyes in sufficient quantities to cause serious or even fatal illness [38]. Granular pesticides pose a particular hazard to the eyes depending on individual particles' size and weight [39]. Due to the presence of volatile components of pesticides, their potential for respiratory exposure is great [40]. Inhalation of sufficient amounts of pesticides may cause serious damage to the nose, throat, and lung tissues [37].

\subsection{Effects of pesticides on human health.}

Those with eminent denunciation to a mix of pesticides, including organophosphates, had resulted in the loss of short-term memory, hand-eye coordination, and drawing ability, when in fact obscured children of the same tribe revealed ordinary development [41]. Pesticides cause cancer. A substantial body of epidemiological exhibits links to this fact, particularly child cancer following from both patriarchal and direct nonage exposures. For leukemia and brain cancer, exhibits are powerful, but there are exhibits also for confederation with non-Hodgkin's lymphoma, neuroblastoma, Ewing's sarcoma (a cancer of bone tissue), and Wilm's tumor 
(kidney) [42]. Also, breast, lung, multiple myeloma, non-Hodgkin's lymphoma, leukemia, ovary, pancreas, prostate, kidney bladder, stomach, colon, rectal, lip, connective tissue, brain, and testicular are several adult cancers linked with denunciation to pesticides. One of these, at least breast, prostate, and testicular cancer, is a conceit to have genesis in betimes developmental denunciations to ecological hormone disruptors [43]. Emerging scientific evidence suggests that diabetes will be affected by exposure to environmental pollutants. A high risk of developing type 2 diabetes and its comorbidities is suspected due to pesticide exposure, particularly organochlorines and metabolites. [44, 45]. The majority of pesticides, including organophosphorus components, are to affect the male reproductive system by such mechanisms as reduction of sperm activities (e.g., counts, motility, viability, and density), inhibition of spermatogenesis, reduction of testis weights, damaging sperm DNA, and increasing abnormal sperm morphology [46, 47].

\section{Bioremediation}

Discharge of toxic contaminants from human-made sources results in contamination of various natural resources like water and soil $[48,49]$. It is necessary to destroy the pollutant or to convert them into less toxic forms. This can be achieved by using a technique known as bioremediation; this destroys the contaminants without disturbing surroundings with the help of biological activities [24]. Therefore, bioremediation can be defined as the technology involving various microbes from degrading contaminants to less toxic forms. It is safer, cleaner, eco-friendly, and cost-effective technology [50]. This process involves the oxidation of parent compounds, resulting in carbon dioxide and water that gives energy to the microbe [51]. This process results in complete degradation of the target pollutant as this process does not involve the transfer of contaminants from one place to another (for example, from water to soil or vice-versa) [52]. For biodegradation to be successful, choosing the right microbe in the right place with the right environmental conditions like $\mathrm{pH}$, temperature, and many more is necessary [52]. According to metabolism, there are two types of substrates [51]. Primary substrates are those substrates when the compound's metabolism provides energy to the cell, and the contaminant is referred to as the primary substrate. Secondary substrates are those substrates when cell metabolization provides energy but does not support growth.

The two terms, 'bioremediation' and 'biodegradation', should not be mixed. Biodegradation is a process of degradation, which is a step in bioremediation. Only some contaminants are biodegradable, and only some microorganisms can degrade contaminants [53].

Principle of bioremediation- It is the process of disintegrating or transferring pollutants [54]. Disintegrating is given to microorganisms because they have enzymes that increase the degradation rate [55]. Degradation of contaminants by microorganisms depends on three factors [55]: type of organism, type of contaminant, geological and chemical conditions at the contaminated site.

\subsection{Classification of bioremediation.}

Based on transportation and removal of waste bioremediation is classified into two categories [56]. 


\subsubsection{Ex-situ bioremediation.}

The word 'ex-situ' means away. Therefore ex-situ bioremediation is a process where the treatment of pollutants is done away from the contaminated site with the help of processes like composting, bioreactors, etc. [57]. Contaminated water or soil has to be moved away from the contaminant site to the site with better conditions [58]. Selection of technique depends on the depth of pollution, type of pollutant, degree of pollution, cost of treatment, geographical location, and geological area of the site [59].

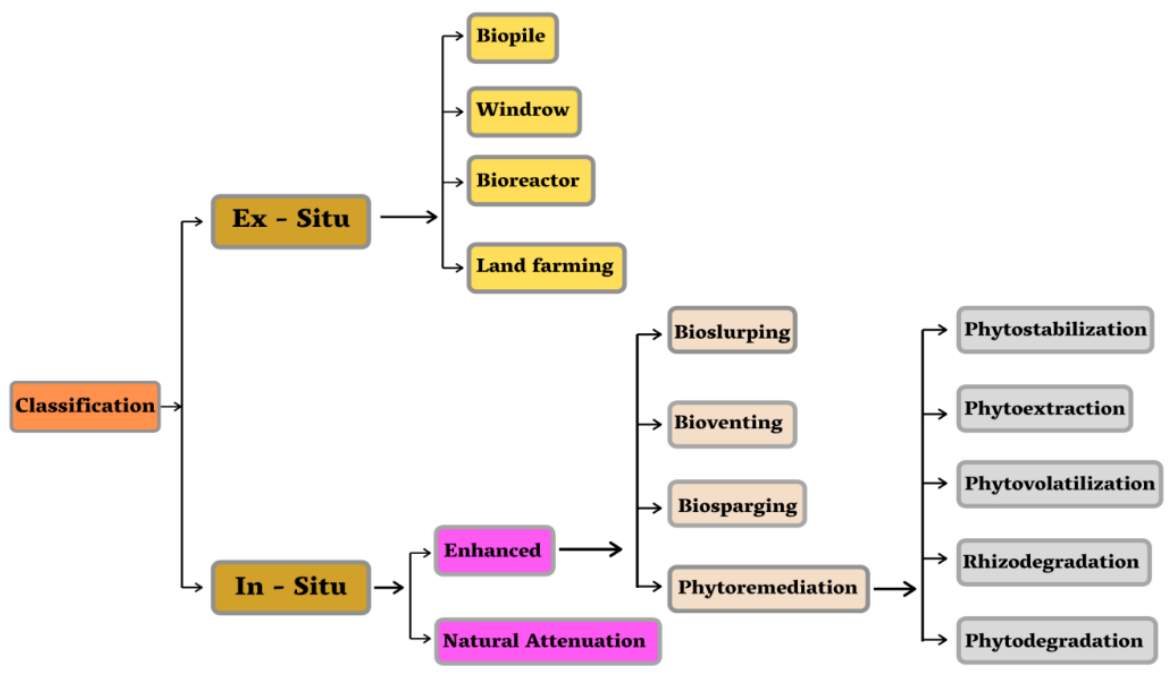

Figure 3. Classification of bioremediation based on transportation and waste removal.

\subsubsection{Biopile.}

It is a technique used to enhance bioremediation by increasing microbial activities. Contaminated soil or water is excavated, and extra nutrients are added, followed by aeration. This technique can also be used to treat pollutants in extreme climates also [60-63].

\subsubsection{Windrows.}

It is a technique used to enhance bioremediation by increasing degradation activities. Due to its tendency to remove hydrocarbon, it is more preferred to treat polluted soil compared to contaminated water [64].

\subsubsection{Bioreactors.}

Bioreactors are the container in which biodegradation of pollutants is done under suitable conditions by mixing contaminants with suitable microbes [57]. Different operating modes of bioreactors are batch, fed-batch, sequencing batch, multistage and continuous. The main advantage of a bioreactor is its excellent control over bioprocess parameters like $\mathrm{pH}$, temperature, agitation, aeration rate, and column concentration [60].

\subsubsection{Land farming.}

It is the simplest technique owing to less cost and less equipment. There is a large debate on whether land farming is in-situ or ex-situ; it depends on pollution depth. Suppose the depth of the pollutant is less than 1 meter. In that case, it is said in-situ because excavation is not 
necessary. In contrast, if the depth of the pollutant is greater than 1 meter, it is said to be exsitu [65].

\subsubsection{In-situ bioremediation.}

The word 'in-situ' means inside. Therefore in-situ bioremediation is a process where the treatment of pollutants is done inside the contaminant with the help of processes like biostimulation, bio-venting, bioaugmentation, etc. [65]. It does not require excavation. Ideally, these techniques are the least expensive. Status of electron acceptor, moisture content, $\mathrm{pH}$, temperature, and nutrient availability are important environmental conditions for this process $[59,60]$.

\subsubsection{Natural attenuation.}

It is a process which utilizes natural biodegradation of contaminated site. It makes the biological decay of pollutants easier. It is also known as passive or intrinsic remediation [66].

\subsubsection{Enhanced bioremediation.}

It is the process of bioremediation in which microorganisms like fungi, bacteria, and other microbe degrade contaminants found in groundwater in harmless forms. In this process, stimulating materials are added, including nutrients, nitrogen, and phosphorous, increasing microbial growth [67].

\subsection{Bioslurping.}

It is a technique used to achieve soil and groundwater remediation. It combines vacuum pumping, bioventing, soil vapor extraction by stimulation of contaminant biodegradation [68]. It is difficult to establish a vacuum on a deep high because it may create saturated soil lenses that are difficult to aerate [59].

\subsection{Bioventing.}

It is the process of providing suitable conditions to microbes for proliferation and enhancing the degradation process of any aerobically degradable compound [69]. The addition of nutrients and moisture is done to enhance bioremediation [59].

\subsection{Biosparging.}

In this technique, the air is injected into the soil surface to increase microbial activities to promote pollutants from the contaminated site [60]. This technique is mostly used to treat aquifers contaminated by petroleum [70].

\subsection{Phytoremediation.}

The process involving plants for the environmental cleanup is known as phytoremediation [71, 72]. It requires a long time period, large area, climatic conditions, etc. This can be achieved by different processes that are mentioned below. 


\subsection{Phytovolatilization.}

Plants absorb contaminants from the soil and release them into the gaseous atmosphere in an unstable form through the process of transpiration [73].

\subsection{Rhizodegradation.}

It is the symbiotic relationship between plants and microbes. It is the breakdown of the contaminants due to the presence of protein, enzymes by plants or soil organisms in the Rhizosphere [74].

\subsection{Phytodegradation.}

Breaking down complex compounds into a simpler form by plants and microorganisms is associated with them [73].

\subsection{Phytoextraction.}

Plants take up the contaminants from water and pass them from the roots to the plant's upper parts [75].

\subsection{Phytostabilization.}

Certain plant species are used to bring contaminants from water and soil [76].

\subsection{Depending on factors.}

\subsubsection{Energy sources.}

Bacteria reduce organic matter to serve energy to degrade pollutants faster. Faster degradation depends on microbial biomass, $\mathrm{pH}$, temperature, and substrate [77].

\subsubsection{Bioavailability.}

The microbial cell converts contaminant into a less toxic form. This conversion depends on the rate of up-taking contaminant, metabolism, and cell transfer rate [78].

\subsubsection{Nutrient.}

Contaminated soil contains microorganisms. But the number of microorganisms present doesn't need to be always equal to required for achieving bioremediation. Therefore, extra nutrients allow the microbe to create enzymes that further break down contaminants [79].

\subsubsection{Microbial stain.}

Stains can adjust themselves in any condition and can also grow at an extreme temperature $[80,81]$.

\subsubsection{Temperature.}

The biochemical reaction rate is regulated by temperature. Generally, rates double at each $10^{\circ} \mathrm{C}$ rise in temperature. However, cells start degenerating after reaching to particular temperature $[80,82]$. Nevertheless, higher temperature ranges like $30^{\circ} \mathrm{C}-40^{\circ} \mathrm{C}$ make degradation in an aqueous medium faster [83]. 
3.2.6. $\mathrm{pH}$.

Most of the microorganisms grow over a narrow $\mathrm{pH}$ range. It ranges from 6.5 to 8.5 , considered as most favorable $[77,82]$.

\subsubsection{Moisture.}

Optimal moisture range between 50-80\%. Excess moisture reduces the amount of oxygen $[77,82]$.

\subsubsection{Concentration of contaminant.}

Microbial activity depends on the concentration of contaminants. Bacterial degradation enzymes are prevented from induction in case of low concentration [84].

\subsubsection{Surfactants.}

Surfactants like T-MAZ 28, T-MAZ 10, and T-MAZ 60 are added to polluted water to increase hydrophobic contaminants' mass transfer [84-85]. Some microbes also produce surfactants to minimize contaminants $[83,86]$.

\subsection{Factors affecting pesticide bioremediation.}

Bioremediation of pesticides depends on multiple environmental and nutritional conditions.

\subsubsection{Microbial population.}

The rate of degradation directly depends on the presence of microbes present in the contaminated site. Usually, native microbes are responsible for biodegradation. Biodegradation potential is determined by microbial density, interaction with other microbes, and their distribution. Microbe's ability to produce particular enzymes affects the rate of pesticide removal from contaminated sites [87].

\subsubsection{Pesticide composition.}

Biodegradation rate depends on pesticide as every pesticide differs in its physical and chemical composition. The degree of pesticide remediation depends on structure, chemical groups, and their molecular weight. Complex the structure of chemical group harder will be the biodegradation [87].

\subsubsection{Concentration of microbes.}

The concentration of microbes is also said to be an important factor. As high concentration increases, the toxicity and low concentration may not be recognized [87].

\subsubsection{Environment Factor}

Different parameters like $\mathrm{pH}$, humidity, soil properties, and nutrition sources are set for pesticide remediation for different environmental conditions. Microbes perform effectively in the presence of effective and special conditions. Different microbes need different optimum conditions. Suitable conditions are necessary for the growth, survival, and metabolic activity of a particular microorganism. The structure and function of microbial activity depend on 
temperature, and moisture [87-88]. In low-temperature natural degradation is very slow. The rate of microbial activity increases with temperature till the temperature reaches any optimum value. After achieving a particular value, activity stops [89]. Moisture provides adequate water, which enhances microbial activity [89]. Microbial proliferation depends on acidic and alkaline medium [90]. Acidic, alkaline natures are $\mathrm{pH}$ of a compound. $\mathrm{pH}$ indicates the potential for microbial growth [91]. A slight change in $\mathrm{pH}$ can also show inferior results [92].

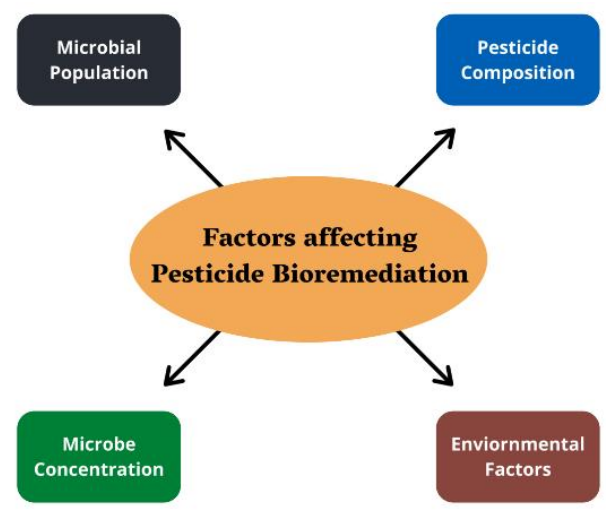

Figure 4. Factors affecting pesticide bioremediation.

\section{Bioremediation by Microalgae of Pesticide Contaminated Water}

An alga plays an important role in returning the actual state of the environment which is altered by various contaminants. A process involving the use of algae to remove pollutants from the environment or convert them into harmless forms is known as phytoremediation. Algae are highly adaptive in nature. They can grow heterotrophically, autotrophically, and mixotrophically depending on the availability of substrate and light. This can increase its chances to survive in harsh climates [16]. Microalgae can absorb many pollutants during their photosynthesis in water [93]. Microalgae increase oxygen concentration in water that increases the growth of several degraders, and oxygen production also decreases the need for external aeration, which is needed for aerobic biodegradation. [94]. With their association with heterotrophic microorganisms, microalgae can do the degradation of several complex pesticides (complexity of pesticide depends on its chemical structure) [94]. Aquatic system contamination is one of the most serious problems that the environment has faced [95]. Researchers have told green algae to have the ability to degrade several pesticides like prometryne [96]. Four main steps are involved in microalgae generation, (i) site selection (ii) cultivation (iii) harvesting, and (iv) extraction [93]. Cultivation of algae requires light, carbon dioxide, water, and inorganic salts, whereas the growth medium should be rich in inorganic elements like nutrient, phosphorous, nitrogen, iron, and silicon [97]. Pre and post-treatment of contaminated sites are very much important to regulate microbial growth. The pre-treatment that is the color of the container during cultivation affects the growth and photosynthesis of microalgae. Improving effluent quality is the main step of post-treatment [96, 98, 99]. But, both pre-treatment and post-treatment requires extra cost and energy [98]. Blue-green algae, widely known as cyanobacteria, are used to estimate organophosphorus pesticide growth [100]. Moreover, microalgae tend to use solar energy and converting it into biomass [100]. Microbial biomass is largely used in the feedstock in the manufacturing of several products. Therefore, microalgae-based technology has many opportunities in environmental and product development applications [93]. 


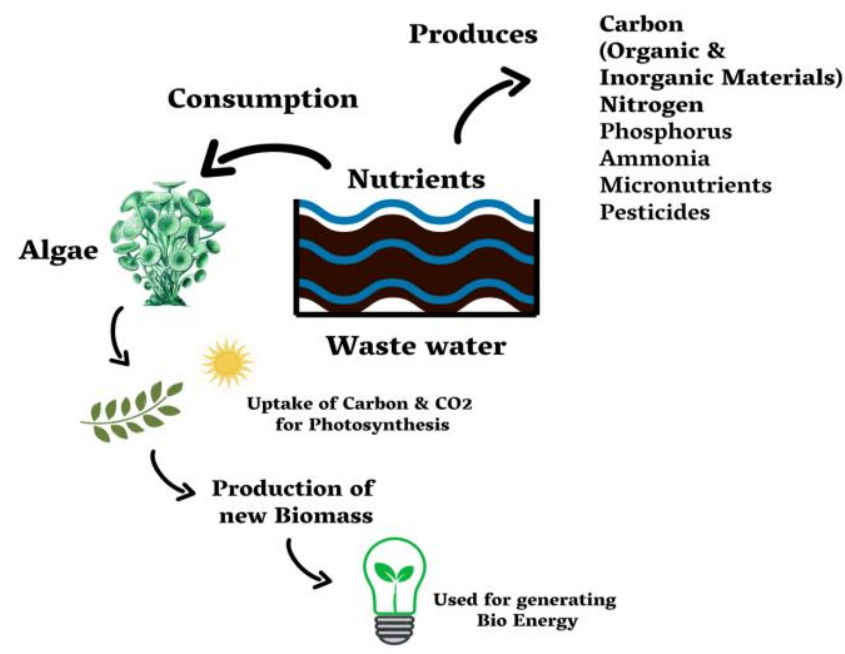

Figure 5. Bioremediation by microalgae of pesticide-contaminated water.

\subsection{Generation of algae.}

Algae-based generation involves several steps [101-104].

Table 1. The difference between open and closed sites [101-104].

\begin{tabular}{|c|c|c|}
\hline Property & Open Type & Close Type \\
\hline Made up of & Naturally made & Glass and plastic \\
\hline Management & Easy to manage & Difficult to manage \\
\hline Energy & Low energy demand & $\begin{array}{l}\text { High energy demand but the low energy } \\
\text { consumption }\end{array}$ \\
\hline Depth & Usually, 0.2-0.4 meter allow light to pass & $\begin{array}{l}\text { The diameter of the container depends on } \\
\text { the mixing method }\end{array}$ \\
\hline Contamination & $\begin{array}{l}\text { High risk of contamination as the site is } \\
\text { exposed to an outdoor environment }\end{array}$ & Low risk of contamination \\
\hline Growth medium & $\begin{array}{l}\text { Due to rain and precipitation, there are changes } \\
\text { in growth medium }\end{array}$ & Growth medium remains constant \\
\hline Concentration & Changes due to evaporation & Concentration remains constant \\
\hline Productivity & Less & High \\
\hline Cost & Cost-effective & Costly \\
\hline Cleaning system & Easy & Difficult \\
\hline Preference & Less & More \\
\hline Example & Tank, pond, and lake & Created artificially \\
\hline
\end{tabular}

\subsubsection{Cultivation.}

Different technologies are used for microalgae development. Cultivation is achieved by the photoautotrophic, heterotrophic, mixotrophic method [105]. The photoautotrophic process uses light to convert carbon dioxide into chemical energy. In the heterotrophic process, there is no light source needed [106]. In the mixotrophic process, both organic carbon and inorganic carbon are used [105]. Two widely accepted cultivated methods are high rate algae pond and photobioreactors [101].

\subsubsection{High rate algae pond.}

Low energy is required for the cultivation, which produces higher biomasses [107]. For the effective efficiency of this method, a large area is required [108]. The main disadvantage of this method is that it has few environmental implementations compared to other technologies [109-110]. 


\subsubsection{Photobioreactors.}

It is a type of bioreactor that depends on the light source for the cultivation of microalgae. Several types of photobioreactors are designed for microalgae cultivation depending on the yield of biomass generation [111]. The photobioreactor's efficiency depends on the availability of light, carbon dioxide feed, cultivation feed, circulation system, and cost [101]. The main advantage of the photobioreactor over other methods is its low contamination rate [101].

\subsubsection{Harvesting.}

After the development of microalgae in the culture medium, it is harvested for further analysis and application. Harvesting is done to extract useful biomass for valuable product generation [112]. Different methods such as flocculation, centrifugation, floatation, filtration, gravity sedimentation, and screening are used for microalgae recovery [113].

\subsubsection{Extraction.}

Extraction of biomass for further processing is done to add final value to bioproducts [101].

\subsection{Metabolic mechanism of pesticide removal by microalgae.}

Different methods are there for pesticide removal by microalgae.

\subsubsection{Bioadsorption.}

It is the passive process in which microalgae absorb pesticides and other pollutants [113-114]. This process involves different mechanisms like electrostatic interaction, surface complexion, absorption, and ion exchange. Therefore, pesticide absorption effectiveness is affected by surface-active groups and properties of microalgae [115-118]. This method mainly depends on two aspects (i) optimal condition of the biome, its continued existence, and its activity (ii) structure of pesticide, factors affecting microalgae. Alternatively, this technique is affected by $\mathrm{Ph}$, temperature, salinity, substrate, surface bonding, redox potential, surface tension, water available, and light quality. The Microalgae cell wall is made up of carbohydrates, fibril matrix, intercellular space, and sulfated polysaccharides, which make contamination absorption from the water much easier [105, 119].

\subsubsection{Bioaccumulation.}

It is the active process that is represented by the bio-concentration factor (BCF). It is a concentration quotient of a pollutant in an organism concerning the surrounding environment $[113,120]$. Biocentration mechanism, the bioavailability of chemicals, physical barrier, methods of determination, metabolism, interspecies variation, ionization of compounds, environmental condition, and dissolved organic matter are factors affecting BCF value [121]. In this method, microalga is exposed to organic contamination like a pesticide that is induced to the production of reactive oxygen species (ROS). Generated ROS can cause oxidation in DNA and membrane lipids, resulting in functional disorder in algae cells or cell death [122124]. Many antioxidant enzymes are responsible for RAS removal for algae cell damage [125]. It has been verified that microalgae can bioaccumulate and biodegrade pesticide. 


\subsubsection{Biodegradation.}

In this process, microalgae can degrade pesticides into small molecules that serve as a nutrient source for microalgae growth [126]. Biodegradation is highly affected by the presence of a suitable enzyme. The particular enzyme does the degradation of a particular pesticide faster. Biodegradation of pesticide is a multistep process [127-130] that includes, The activation of pesticide in the absence of a functional group. Formation of conjugation with glutathione, glucose, and malonate. Transportation of such conjugation. Further, the process depends on the nature of pesticide and microbial mechanisms [114].

\subsection{Biomass generation and its economic benefit.}

Wastewater contains lots of heavy nutrients like organic and inorganic carbon, nitrogen, nitrate, nitrite, ammonium, phosphate, polyphosphate, orthophosphate, micronutrient, and heavy metals. Microalgae directly up-taking surrounding pollutants or nutrients by different mechanisms like bioaccumulation, bioabsorption, biodegradation, and assimilation [131-132]. Further, a microalga takes organic carbon and carbon dioxide by photosynthesis mechanism [132-133] to produce new biomass [131]. New biomass is used in generating bioenergy. Diagrammatic representation of the process, economic benefits of generated biomass - is the cheapest energy source. Energy generated from biomass is utilized in cooking, space heating, and numerous industrial processes [134]. It reduces rural poverty by adding income generation as the biomass system is mostly retained locally [134]. In many forestry or agriculture-based energy, biomass serves as a defendable, cheapest, and abundant fuel, further decreasing energy cost [134]. Feedstock production from biomass can be primary employment and secondary income in several areas [134]. Biomass produces biofuels, and the demand for biofuel may also increase farm income [135]. Fossil fuel requires heavy capital, gas pipeline, oil drill, fuel collection. But a generation from biomass is much cheaper. Manufacturers can produce the same output by cheaper input using biomass [136]. Biomass is used in biochar production [114].

\subsection{Advantages and disadvantages.}

\subsubsection{Advantages.}

Being cost-friendly, the remediation process requires low energy than other conventional methods [2]. Micro-algae uses solar energy for production; therefore, this treatment does not demand an external energy source [137]. A single step of microalgae biofenry produces only a single byproduct [2]. This remedial method produces a highly purified product [138]. Value-added molecules can be recovered easily [138]. Obtained biomass after this treatment is economically benefited [139]. Microalgal remediation shows efficient removal of pathogens and efficient nutrient recovery [140] and minimizes chemical and biological sludges [16].

\subsubsection{Disadvantages.}

The significant disadvantage is the high cost of biofenry process [141, 142]. It requires temperature maintenance[138]. In particular times, the biomediation process may require periodic cleaning in some cases [66]. In contrast, it is difficult to maintain monocultures in certain cases [2]. 


\section{Conclusions}

Pesticides are known as the cause of the most dangerous threat to a biological organism. Therefore, out of all toxic substances, runoff in water pesticides are considered the most serious issue. Pesticides should be removed from water bodies for human safety. Best method to remove pesticide contaminations is bioremediation. Bioremediation is considered to be the safest, easiest method. This technique involves the use of biological microorganisms for degrading pollutants without harming other activities. This technique is based on biodegradation. This technique is effective only when environmental conditions permit the growth of microbes. The selection of the type of bioremediation technology depends on the type of pesticide and surrounding conditions. Algae microorganism forms a large group of biodiversity and considered as a potent group of bioremediants. Phytoremediation would expand to more scientific branches of bioremediation and is also be able to respond quickly to all the future challenges. Further research can be made to use less light sources or be made cost-effective for biofenry process. Future advances can be made for pathways of degradation of several pesticides.

\section{Funding}

This review received no external funding.

\section{Acknowledgments}

The authors sincerely thank the reviewers for providing helpful comments on earlier drafts of the manuscript.

\section{Conflicts of Interest}

The authors declare no conflict of interest.

\section{References}

1. Wollmann, F.; Dietze, S.; Ackermann, J. U.; Bley, T.; Walther, T.; Steingroewer, J.; Krujatz, F. Microalgae wastewater treatment: biological and technological approaches. Engineering in Life Sciences, 2019, 19, 860871. https://doi.org/10.1002/elsc.201900071.

2. Goswami, R. K.; Mehariya, S.; Verma, P.; Lavecchia, R.; Zuorro, A. Microalgae-based biorefineries for sustainable resource recovery from wastewater. Journal of Water Process Engineering, 2020, 40, 101747. https://doi.org/10.1016/j.jwpe.2020.101747.

3. Boudh, S.; Singh, J. S. Pesticide contamination: environmental problems and remediation strategies. In Emerging and eco-friendly approaches for waste management; Springer Singapore, 2019, 245-269. https://doi.org/10.1007/978-981-10-8669-4_12.

4. Nie, J.; Sun, Y.; Zhou, Y.; Kumar, M.; Usman, M., Li, J.; Tsang, D. C. Bioremediation of water containing pesticides by microalgae: mechanisms, methods, and prospects for future research. Science of The Total Environment, 2020, 707, 136080. https://doi.org/10.1016/j.scitotenv.2019.136080.

5. Upadhayay, J.; Rana, M.; Juyal, V.; Bisht, S. S.; Joshi, R. Impact of pesticide exposure and associated health effects. Pesticides in crop production: physiological and biochemical action, 2020, 69-88. https://doi.org/10.1002/9781119432241.ch5.

6. Watts, D.; Valdés, M. F.; Jara, D.; Watson, A. Potential residential PV development in Chile: The effect of Net Metering and Net Billing schemes for grid-connected PV systems. Renewable and Sustainable Energy Reviews, 2015, 41, 1037-1051. https://doi.org/10.1016/j.rser.2014.07.201. 
7. Cho, S.; Luong, T. T.; Lee, D.; Oh, Y. K.; Lee, T. Reuse of effluent water from a municipal wastewater treatment plant in microalgae cultivation for biofuel production. Bioresource technology, 2011, 102, 86398645. https://doi.org/10.1016/j.biortech.2011.03.037.

8. Udaiyappan, A. F. M.; Hasan, H. A.; Takriff, M. S.; Abdullah, S. R. S. A review of the potentials, challenges and current status of microalgae biomass applications in industrial wastewater treatment. Journal of Water Process Engineering, 2017, 20, 8-21. https://doi.org/10.1016/j.jwpe.2017.09.006.

9. Kumar, R.; Pal, P. Assessing the feasibility of $\mathrm{N}$ and $\mathrm{P}$ recovery by struvite precipitation from nutrient-rich wastewater: a review. Environmental Science and Pollution Research, 2015, 22, 17453-17464. https://doi.org/10.1007/s11356-015-5450-2.

10. Gurung, K.; Tang, W. Z.; Sillanpää, M. Unit energy consumption as benchmark to select energy positive retrofitting strategies for Finnish wastewater treatment plants (WWTPs): a case study of Mikkeli WWTP. Environmental Processes 2018, 5, 667-681. https://doi.org/10.1007/s40710-018-0310-y.

11. Lemaire, R.; Gulsum, Y.; Keller, J.; Yuan, Z. Simultaneous Nitrification, Denitrification, and Phosphorus Removal From Nutrient-Rich Industrial Wastewater Using Granular Sludge.[Short Platform Presentation]. 2008.

12. Capodaglio, A. G.; Olsson, G. Energy issues in sustainable urban wastewater management: Use, demand reduction and recovery in the urban water cycle. Sustainability, 2020, 12(1), 266.

13. Abdelgadir, A.; Chen, X.; Liu, J.; Xie, X.; Zhang, J.; Zhang, K.; Liu, N. Characteristics, process parameters, and inner components of anaerobic bioreactors. BioMed research international 2014. https://doi.org/10.1155/2014/841573.

14. Liu, C.; Shi, W.; Li, H.; Lei, Z.; He, L.; Zhang, Z. Improvement of methane production from waste activated sludge by on-site photocatalytic pre-treatment in a photocatalytic anaerobic fermenter. Bioresource technology 2014, 155, 198-203. https://doi.org/10.1016/j.biortech.2013.12.041.

15. Bhatnagar, S.; Kumari, R. Bioremediation: a sustainable tool for environmental management-a review. Annual Research \& Review in Biology, 2013, 974-993.

16. Rusten, B.; Sahu, A. K. Microalgae growth for nutrient recovery from sludge liquor and production of renewable bioenergy. Water science and technology 2011, 64, 1195-1201. https://doi.org/10.2166/wst.2011.722.

17. Mahmood, I.; Imadi, S. R.; Shazadi, K.,; Gul, A.; Hakeem, K. R. Effects of pesticides on environment. In Plant, soil and microbes; Springer, Cham, 2016, pp. 253-269. https://doi.org/10.1007/978-3-319-274553_13.

18. Cooper, J.; Dobson, H. The benefits of pesticides to mankind and the environment. Crop Protection 2007, 26, 1337-1348. https://doi.org/10.1016/j.cropro.2007.03.022.

19. Importance \& Benefits of Pesticide, Pesticide Facts. [Accessed on 24 ${ }^{\text {th }}$ December, 2020] Available at https://pesticidefacts.org/topics/necessity-of-pesticides/.

20. Hageman, K. J.; Simonich, S. L.; Campbell, D. H.; Wilson, G. R.; Landers, D. H. Atmospheric deposition of current-use and historic-use pesticides in snow at national parks in the western United States. Environmental Science \& Technology 2006, 40, 3174-3180. https://doi.org/10.1021/es060157c.

21. Li, H.; Zeng, E. Y.; You, J. Mitigating pesticide pollution in China requires law enforcement, farmer training, and technological innovation. Environmental toxicology and chemistry, 2014, 33, 963-971. https://doi.org/10.1002/etc.2549.

22. Eldridge, B. F. Pesticide application and safety training for applicators of public health pesticides. VectorBorne Disease Section 2008

23. Yadav, I. C.; Devi, N. L. Pesticides classification and its impact on human and environment. Environmental science and engineering 2017, 6, 140-158.

24. Maksymiv, I. Pesticides: benefits and hazards. Journal of Vasyl Stefanyk Precarpathian National University 2015, 2, 70-76.

25. DeLorenzo, M. E.; Scott, G. I.; Ross, P. E. Toxicity of pesticides to aquatic microorganisms: a review. Environmental Toxicology and Chemistry: An International Journal 2001, 20, 84-98. https://doi.org/10.1002/etc.5620200108.

26. Kramer, W.; Buchel, K. H. Chemistry of Pesticides. John Wiley and Sons, New York, NY, 1983, $280-281$.

27. Hoffman, D. J.; Rattner, B. A.; Burton Jr, G. A.; Cairns Jr, J. (Eds.). Handbook of ecotoxicology. CRC press. 2002. 
28. Garcia, F. P.; Ascencio, S. Y. C.; Oyarzún, J. C. G.; Hernandez, A. C.; Alavarado, P. V. Pesticides: classification, uses and toxicity. Measures of exposure and genotoxic risks. J. Res. Environ. Sci. Toxicol 2012, $1,279-293$.

29. Winder, C. Occupational toxicology of the nervous system. Occupational Toxicology, 2004, 164.

30. Yadav, I. C.; Devi, N. L. Pesticides classification and its impact on human and environment. Environmental science and engineering 2017, 6, 140-158.

31. Anju, A.; Ravi S, P.; Bechan, S. Water pollution with special reference to pesticide contamination in India. Journal of Water Resource and Protection 2010, 2, 432-448. http://dx.doi.org/10.4236/jwarp.2010.25050.

32. Fishel, F. M.; Ferrell, J. A. Managing pesticide drift. EDIS 2010. Retrieved from https://journals.flvc.org/edis/article/view/118806.

33. Anderson, S. E.; Meade, B. J. Potential health effects associated with dermal exposure to occupational chemicals. Environmental health insights 2014, 8, EHI-S15258. https://doi.org/10.4137\%2FEHI.S15258.

34. Sankhla, M. S.; Kumari, M.; Sharma, K.; Kushwah, R. S.; Kumar, R. Water contamination through pesticide $\&$ their toxic effect on human health. International Journal for Research in Applied Science and Engineering Technology 2018, 6, 967-970.

35. Salvatore, A. L.; Bradman, A.; Castorina, R.; Camacho, J.; López, J.; Barr, D. B.; Eskenazi, B. Occupational behaviors and farmworkers' pesticide exposure: findings from a study in Monterey County, California. American journal of industrial medicine 2008, 51, 782-794. https://doi.org/10.1002/ajim.20622.

36. Damalas, C. A.; Eleftherohorinos, I. G. Pesticide exposure, safety issues, and risk assessment indicators. International journal of environmental research and public health 2011, 8, 1402-1419. https://doi.org/10.3390/ijerph8051402.

37. Gilden, R. C.; Huffling, K.; Sattler, B. Pesticides and health risks. Journal of Obstetric, Gynecologic \& Neonatal Nursing 2010, 39, 103-110. https://doi.org/10.1111/j.1552-6909.2009.01092.x.

38. Jaga, K.; Dharmani, C. Ocular toxicity from pesticide exposure: A recent review. Environmental health and preventive medicine 2006, 11, 102-107. https://doi.org/10.1265/ehpm.11.102.

39. Amaral, A. F. Pesticides and asthma: challenges for epidemiology. Frontiers in public health 2014, $2,6$. http://dx.doi.org/10.3389/fpubh.2014.00006.

40. Guillette, E. A.; Meza, M. M.; Aquilar, M. G.; Soto, A. D.; Garcia, I. E. An anthropological approach to the evaluation of preschool children exposed to pesticides in Mexico. Environmental Health Perspectives 1998, 106, 347-353. https://doi.org/10.1289/ehp.98106347.

41. Infante-Rivard, C.; Weichenthal, S. Pesticides and childhood cancer: an update of Zahm and Ward's 1998 review. Journal of Toxicology and Environmental Health, Part $B$ 2007, 10, 81-99. https://doi.org/10.1080/10937400601034589.

42. Bassil, K. L.; Vakil, C.; Sanborn, M.; Cole, D. C.; Kaur, J. S.; Kerr, K. J. Cancer health effects of pesticides: systematic review. Can Fam Physician 2007, 53, 1704-1711.

43. Sylvie Azandjeme, C.; Bouchard, M.; Fayomi, B.; Djrolo, F.; Houinato, D.; Delisle, H. Growing burden of diabetes in sub-saharan Africa: contribution of pesticides?. Current diabetes reviews 2013, 9, 437-449.

44. Kim, K. H.; Kabir, E.; Jahan, S. A. Exposure to pesticides and the associated human health effects. Science of the Total Environment 2017, 575, 525-535, https://doi.org/10.1016/j.scitotenv.2016.09.009.

45. Michalakis, M.; Tzatzarakis, M. N.; Kovatsi, L.; Alegakis, A. K.; Tsakalof, A. K.; Heretis, I.; Tsatsakis, A. Hypospadias in offspring is associated with chronic exposure of parents to organophosphate and

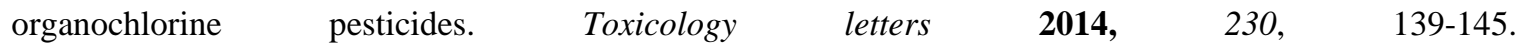
http://dx.doi.org/10.1016/j.toxlet.2013.10.015.

46. Mehrpour, O.; Karrari, P.; Zamani, N.; Tsatsakis, A. M.; Abdollahi, M. Occupational exposure to pesticides and consequences on male semen and fertility: a review. Toxicology letters 2014, 230, 146-156. https://doi.org/10.1016/j.toxlet.2014.01.029.

47. Scott, G. I.; Moore, D. W.; Fulton, M. H.; Hampton, T. W.; Chandler, G. T.; Jackson, K. L.; Patterson, E. R. Agricultural insecticide runoff effects on estuarine organisms: Correlating laboratory and field toxicity testing with ecotoxicological biomonitoring. 1988, US Environmental Protection Agency, Gulf Breeze Environmental Research Laboratory.

48. Kumari, R.; Kaur, I.; Bhatnagar, A. K. Enhancing soil health and productivity of Lycopersicon esculentum Mill. using Sargassum johnstonii Setchell \& Gardner as a soil conditioner and fertilizer. Journal of applied phycology 2013, 25, 1225-1235. https://doi.org/10.1007/s10811-012-9933-y. 
49. Prescott, L.M.; Harley, J.P; Klein, D.A. Microbiology: Food and Industrial Microbiology. 5th Edition, McGraw-Hill, Boston, 2002, 978-981.

50. Pandey, B.; Fulekar, M. H. Bioremediation technology: A new horizon for environmental cleanup. Biology and Medicine 2012, 4, 51.

51. Vidali, M. Bioremediation. an overview. Pure and applied chemistry, 2001, 73, 1163-1172. https://doi.org/10.1351/pac200173071163.

52. Walsh, J. B. A feasibility study of bioremediation in a highly organic soil. Master of Science Thesis, Worcester Polytechnic Institute. 1999.

53. Shishir, T. A.; Mahbub, N.; Kamal, N. E. Review on bioremediation: a tool to resurrect the polluted rivers. Pollution 2019, 5, 555-568. https://dx.doi.org/10.22059/poll.2019.272339.558.

54. National Research Council. In situ bioremediation: When does it work?. National Academies Press. 1993

55. Uqab, B.; Mudasir, S.; Nazir, R. Review on bioremediation of pesticides. J Bioremed Biodeg 2016, 7, 343.

56. Thijs, S.; Sillen, W.; Weyens, N.; Vangronsveld, J. Phytoremediation: state-of-the-art and a key role for the plant microbiome in future trends and research prospects. International journal of phytoremediation 2017, 19, 23-38. https://doi.org/10.1080/15226514.2016.1216076.

57. Harekrushna, S.; Kumar, D. C. A review on: bioremediation. International Journal of Research in Chemistry and Environment 2012, 2, 13-21.

58. Kumar, V.; Dwivedi, S. K. Bioremediation mechanism and potential of copper by actively growing fungus Trichoderma lixii CR700 isolated from electroplating wastewater. Journal of Environmental Management 2021, 277, 111370. https://doi.org/10.1016/j.jenvman.2020.111370.

59. Azubuike, C. C.; Chikere, C. B.; Okpokwasili, G. C. Bioremediation techniques-classification based on site of application: principles, advantages, limitations and prospects. World Journal of Microbiology and Biotechnology 2016, 32, 1-18. https://doi.org/10.1007/s11274-016-2137-x.

60. Parween, T.; Bhandari, P.; Sharma, R.; Jan, S.; Siddiqui, Z. H.; Patanjali, P. K. Bioremediation: a sustainable tool to prevent pesticide pollution. In Modern Age Environmental Problems and their Remediation, Springer, Cham, 2018, pp. 215-227. https://doi.org/10.1007/978-3-319-64501-8_12.

61. Dias, R. L.; Ruberto, L.; Calabró, A.; Balbo, A. L.; Del Panno, M. T.; Mac Cormack, W. P. Hydrocarbon removal and bacterial community structure in on-site biostimulated biopile systems designed for bioremediation of diesel-contaminated Antarctic soil. Polar biology 2015, 38, 677-687. https://doi.org/10.1007/s00300-014-1630-7.

62. Gomez, F.; Sartaj, M. Optimization of field scale biopiles for bioremediation of petroleum hydrocarbon contaminated soil at low temperature conditions by response surface methodology (RSM). International Biodeterioration \& Biodegradation 2014, 89, 103-109. https://doi.org/10.1016/j.ibiod.2014.01.010.

63. Whelan, M. J.; Coulon, F.; Hince, G.; Rayner, J.; McWatters, R.; Spedding, T.; Snape, I. Fate and transport of petroleum hydrocarbons in engineered biopiles in polar regions. Chemosphere 2015, 131, 232-240. https://doi.org/10.1016/j.chemosphere.2014.10.088.

64. Coulon, F.; Al Awadi, M.; Cowie, W.; Mardlin, D.; Pollard, S.; Cunningham, C.; Paton, G. I. When is a soil remediated? Comparison of biopiled and windrowed soils contaminated with bunker-fuel in a full-scale trial. Environmental Pollution 2010, 158, 3032-3040. https://doi.org/10.1016/j.envpol.2010.06.001.

65. Rittmann, B. E.; Seagren, E.; Wrenn, B. A. In situ bioremediation. 1994.

66. Nikolopoulou, M.; Pasadakis, N.; Norf, H.; Kalogerakis, N. Enhanced ex situ bioremediation of crude oil contaminated beach sand by supplementation with nutrients and rhamnolipids. Marine pollution bulletin 2013, 77, 37-44. https://doi.org/10.1016/j.marpolbul.2013.10.038.

67. Juwarkar, A. A.; Misra, R. R.; Sharma, J. K. Recent trends in bioremediation. In Geomicrobiology and biogeochemistry, Springer, Berlin, Heidelberg, 2012, 81-100. https://doi.org/10.1007/978-3-642-41837-2_5.

68. Gidarakos, E.; Aivalioti, M. Large scale and long term application of bioslurping: the case of a Greek petroleum refinery site. Journal of hazardous materials 2007, 149, 574-581. https://doi.org/10.1016/j.jhazmat.2007.06.110.

69. Kao, C. M.; Chen, C. Y.; Chen, S. C.; Chien, H. Y.; Chen, Y. L. Application of in situ biosparging to remediate a petroleum-hydrocarbon spill site: Field and microbial evaluation. Chemosphere 2008, 70, 14921499. https://doi.org/10.1016/j.chemosphere.2007.08.029.

70. Leong, Y. K.; Chang, J. S. Bioremediation of heavy metals using microalgae: Recent advances and mechanisms. Bioresource technology 2020, 303, 122886. https://doi.org/10.1016/j.biortech.2020.122886.

71. Ali, N.; Dashti, N.; Khanafer, M.; Al-Awadhi, H.; Radwan, S. Bioremediation of soils saturated with spilled crude oil. Scientific reports 2020, 10, 1-9. https://doi.org/10.1038/s41598-019-57224-X. 
72. Thijs, S.; Sillen, W.; Weyens, N.; Vangronsveld, J. Phytoremediation: state-of-the-art and a key role for the plant microbiome in future trends and research prospects. International journal of phytoremediation 2017, 19, 23-38. https://doi.org/10.1080/15226514.2016.1216076.

73. Fulekar, M. H. Rhizosphere bioremediation of pesticides by microbial consortium and potential microorganism. International Journal of Current Microbiology and Applied Sciences 2014, 3, 235-248.

74. Singh, T.; Singh, D. K. Phytoremediation of organochlorine pesticides: Concept, method, and recent developments. International journal of phytoremediation $\mathbf{2 0 1 7}, \quad 19, \quad 834-843$. https://doi.org/10.1080/15226514.2017.1290579.

75. Ławniczak, Ł.; Woźniak-Karczewska, M.; Loibner, A. P.; Heipieper, H. J.; Chrzanowski, Ł. Microbial degradation of hydrocarbons_-basic principles for bioremediation: a review. Molecules 2020, $25,856$. https://doi.org/10.3390/molecules25040856.

76. Boopathy, R. Factors limiting bioremediation technologies. Bioresource technology 2000, 74, 63-67. https://doi.org/10.1016/S0960-8524(99)00144-3.

77. Boopathy, R.; Manning, J.; Kulpa, C. F. A laboratory study of the bioremediation of 2, 4, 6-trinitrotoluenecontaminated soil using aerobic/anoxic soil slurry reactor. Water environment research 1998, 70, 80-86. https://doi.org/10.2175/106143098X126919.

78. Kumari, S.; Jamwal, R.; Mishra, N.; Singh, D. K. Recent developments in environmental mercury bioremediation and its toxicity: a review. Environmental Nanotechnology, Monitoring \& Management 2020, 13, 100283. https://doi.org/10.1016/j.enmm.2020.100283.

79. Van Deuren, J.; Lloyd, T.; Chetry, S.; Liou, R.; Peck, J. Remediation Technologies Screening Matrix and Reference Guide., Report by Platinum International, Inc. for US Army Environmental Center. 2002, Report No. SFIM-AEC-ET-CR-97053. Available online: http://www.frtr.gov/matrix2/section1/toc.html.

80. Varshney, K. BIOREMEDIATION OF PESTICIDE WASTE AT CONTAMINATED SITES, 2019.

81. Kensa, V. M. Bioremediation-an overview. I Control Pollution 2011, 27, 161-168.

82. Mishra, M.; Singh, S. K.; Kumar, A. Environmental factors affecting the bioremediation potential of microbes. In Microbe Mediated Remediation of Environmental Contaminants, Woodhead Publishing, 2021, pp. 47-58. https://doi.org/10.1016/B978-0-12-821199-1.00005-5.

83. Adams, G. O.; Fufeyin, P. T.; Okoro, S. E.; Ehinomen, I. Bioremediation, biostimulation and bioaugmention: a review. International Journal of Environmental Bioremediation \& Biodegradation 2015, 3, 28-39.

84. Laha, S.; Tansel, B.; Ussawarujikulchai, A. Surfactant-soil interactions during surfactant-amended remediation of contaminated soils by hydrophobic organic compounds: a review. Journal of Environmental Management 2009, 90, 95-100. https://doi.org/10.1016/j.jenvman.2008.08.006.

85. Shiau, B. J.; Sabatini, D. A.; Harwell, J. H. Properties of food grade (edible) surfactants affecting subsurface remediation of chlorinated solvents. Environ Sci Technol 1995, 29, 2929-2935. https://doi.org/10.1021/es00012a007.

86. Bhat, R. A.; Hakeem, K. R.; Al-Saud, N. B. S. (Eds.). Bioremediation and Biotechnology, Vol 3: Persistent and Recalcitrant Toxic Substances. Springer Nature., 2020, https://doi.org/10.1007/978-3-030-46075-4.

87. Reedich, L. M.; Millican, M. D.; Koch, P. L. Temperature impacts on soil microbial communities and potential implications for the biodegradation of turfgrass pesticides. Journal of environmental quality 2017, 46, 490-497. https://doi.org/10.2134/jeq2017.02.0067.

88. Abatenh, E.; Gizaw, B.; Tsegaye, Z.; Wassie, M. The role of microorganisms in bioremediation-A review. Open Journal of Environmental Biology 2017, 2, 030-046. https://www.peertechz.com/articles/OJEB-2107.php

89. Gangireddygari, V. S. R.; Kalva, P. K.; Ntushelo, K.; Bangeppagari, M.; Tchatchou, A. D.; Bontha, R. R. Influence of environmental factors on biodegradation of quinalphos by Bacillus thuringiensis. Environmental Sciences Europe 2017, 29, 1-10. https://doi.org/10.1186/s12302-017-0109-x.

90. Asira, E. E. Factors that determine bioremediation of organic compounds in the soil. Academic Journal of Interdisciplinary Studies 2013, 2, 125. http://dx.doi.org/10.5901/ajis.2013.v2n13p125.

91. Wang, Q.; Zhang, S.; Li, Y.; Klassen, W. Potential approaches to improving biodegradation of hydrocarbons for bioremediation of crude oil pollution. Journal of environmental protection 2011, 2, 47. https://doi.org/10.4236/jep.2011.21005.

92. Lutzu, G. A.; Ciurli, A.; Chiellini, C.; Di Caprio, F.; Concas, A.; Dunford, N. T. Latest developments in wastewater treatment and biopolymer production by microalgae. Journal of Environmental Chemical Engineering 2020, 9, 104926. https://doi.org/10.1016/j.jece.2020.104926. 
93. Munoz, R.; Guieysse, B. Algal-bacterial processes for the treatment of hazardous contaminants: a review. Water research 2006, 40, 2799-2815. https://doi.org/10.1016/j.watres.2006.06.011.

94. Chen, H.; Wang, Q. Microalgae-based nitrogen bioremediation. Algal Research 2020, 46, 101775. https://doi.org/10.1016/j.algal.2019.101775.

95. Jin, Z. P.; Luo, K.; Zhang, S.; Zheng, Q.; Yang, H. Bioaccumulation and catabolism of prometryne in green algae. Chemosphere 2012, 87, 278-284. https://doi.org/10.1016/j.chemosphere.2011.12.071.

96. Kumar, M.; Sharma, M. P. Production methodology of biodiesel from microalgae. International Journal of Applied Engineering Research 2013, 8, 1825-1832.

97. Serejo, M. L.; Farias, S. L.; Ruas, G.; Paulo, P. L.; Boncz, M. A. Surfactant removal and biomass production in a microalgal-bacterial process: effect of feeding regime. Water Science and Technology 2020, 82, 11761183. https://doi.org/10.2166/wst.2020.276.

98. Maryjoseph, S.; Ketheesan, B. Microalgae based wastewater treatment for the removal of emerging contaminants: A review of challenges and opportunities. Case Studies in Chemical and Environmental Engineering 2020, 2, 100046. https://doi.org/10.1016/j.cscee.2020.100046.

99. Ummalyma, S. B.; Pandey, A.; Sukumaran, R. K.; Sahoo, D. Bioremediation by microalgae: current and emerging trends for effluents treatments for value addition of waste streams. In Biosynthetic technology and environmental challenges, Springer, Singapore, 2018, 355-375. https://doi.org/10.1007/978-981-10-74349_19.

100.Lutzu, G. A.; Ciurli, A.; Chiellini, C.; Di Caprio, F.; Concas, A.; Dunford, N. T. Latest developments in wastewater treatment and biopolymer production by microalgae. Journal of Environmental Chemical Engineering 2020, 9, 104926. https://doi.org/10.1016/j.jece.2020.104926.

101.Borowitzka, M. A.; Moheimani, N. R. Open pond culture systems. In Algae for biofuels and energy, Springer, Dordrecht, 2013, pp. 133-152. https://doi.org/10.1007/978-94-007-5479-9_8.

102.Acién, F. G.; Molina, E.; Reis, A.; Torzillo, G.; Zittelli, G. C.; Sepúlveda, C.; Masojídek, J. Photobioreactors for the production of microalgae. Microalgae-based biofuels and bioproducts 2017, 1-44. https://doi.org/10.1016/B978-0-08-101023-5.00001-7.

103.Li, H.; Watson, J.; Zhang, Y.; Lu, H.; Liu, Z. Environment-enhancing process for algal wastewater treatment, heavy metal control and hydrothermal biofuel production: A critical review. Bioresource technology 2020, 298, 122421. https://doi.org/10.1016/j.biortech.2019.122421.

104.Hammed, A. M.; Prajapati, S. K.; Simsek, S.; Simsek, H. Growth regime and environmental remediation of microalgae. Algae 2016, 31, 189-204. https://doi.org/10.4490/algae.2016.31.8.28.

105.Liang, Y. Producing liquid transportation fuels from heterotrophic microalgae. Applied Energy 2013, 104, 860-868. https://doi.org/10.1016/j.apenergy.2012.10.067.

106. Young, P.; Taylor, M.; Fallowfield, H. J. Mini-review: high rate algal ponds, flexible systems for sustainable wastewater treatment. World journal of microbiology and biotechnology 2017, 33, 117. https://doi.org/10.1007/s11274-017-2282-X.

107. Acién, F. G.; Gómez-Serrano, C.; Morales-Amaral, M. D. M.; Fernández-Sevilla, J. M.; Molina-Grima, E. Wastewater treatment using microalgae: how realistic a contribution might it be to significant urban wastewater treatment?. Applied microbiology and biotechnology 2016, 100, 9013-9022. https://doi.org/10.1007/s00253-016-7835-7.

108. Garfí, M.; Flores, L.; Ferrer, I. Life cycle assessment of wastewater treatment systems for small communities: Activated sludge, constructed wetlands and high rate algal ponds. Journal of Cleaner Production 2017, 161, 211-219. https://doi.org/10.1016/j.jclepro.2017.05.116.

109.Delrue, F.; Álvarez-Díaz, P. D.; Fon-Sing, S.; Fleury, G.; Sassi, J. F. The environmental biorefinery: Using microalgae to remediate wastewater, a win-win paradigm. Energies 2016, 9, 132. https://doi.org/10.3390/en9030132.

110. Streimikiene, D.; Baležentis, T.; Baležentienè, L. Comparative assessment of road transport technologies. Renewable and Sustainable Energy Reviews 2013, 20, 611-618. https://doi.org/10.1016/j.rser.2012.12.021.

111.Uduman, N.; Qi, Y.; Danquah, M. K.; Forde, G. M.; Hoadley, A. Dewatering of microalgal cultures: a major bottleneck to algae-based fuels. Journal of renewable and sustainable energy 2010, 2, 012701. https://doi.org/10.1063/1.3294480.

112.Ardal, E. Phycoremediation of pesticides using microalgae, 2014.

113.Nie, J.; Sun, Y.; Zhou, Y.; Kumar, M.; Usman, M.; Li, J.; Tsang, D. C. Bioremediation of water containing pesticides by microalgae: mechanisms, methods, and prospects for future research. Science of The Total Environment 2020, 707, 136080. https://doi.org/10.1016/j.scitotenv.2019.136080. 
114.Bordbar, S.; Anwar, F.; Saari, N. High-value components and bioactives from sea cucumbers for functional foods_a review. Marine drugs 2011, 9, 1761-1805. https://doi.org/10.3390/md9101761.

115.Fomina, M.; Gadd, G. M. Biosorption: current perspectives on concept, definition and application. Bioresource technology 2014, 160, 3-14. https://doi.org/10.1016/j.biortech.2013.12.102.

116.da Cunha Oliveira, J. A. An integrated use of Macroalgae as bioproducts source and biosorbent for environmental applications. Master, University of Porto, October 2016.

117. Ata, A.; Nalcaci, O. O.; Ovez, B. Macro algae Gracilaria verrucosa as a biosorbent: A study of sorption mechanisms. Algal Research 2012, 1, 194-204. https://doi.org/10.1016/j.algal.2012.07.001.

118.Qiu, Y. W.; Zeng, E. Y.; Qiu, H.; Yu, K.; Cai, S. Bioconcentration of polybrominated diphenyl ethers and organochlorine pesticides in algae is an important contaminant route to higher trophic levels. Science of the Total Environment 2017, 579, 1885-1893. https://doi.org/10.1016/j.scitotenv.2016.11.192.

119.Bi, Y. F.; Miao, S. S.; Lu, Y. C.; Qiu, C. B.; Zhou, Y.; Yang, H. Phytotoxicity, bioaccumulation and degradation of isoproturon in green algae. Journal of hazardous materials 2012, 243, 242-249. https://doi.org/10.1016/j.jhazmat.2012.10.021.

120.Wang, Y.; Wen, Y.; Li, J. J.; He, J.; Qin, W. C.; Su, L. M.; Zhao, Y. H. Investigation on the relationship between bioconcentration factor and distribution coefficient based on class-based compounds: The factors that affect bioconcentration. Environmental toxicology and pharmacology 2014, 38, 388-396. https://doi.org/10.1016/j.etap.2014.07.003.

121.Jin, Z. P.; Luo, K.; Zhang, S.; Zheng, Q.; Yang, H. Bioaccumulation and catabolism of prometryne in green algae. Chemosphere 2012, 87, 278-284. https://doi.org/10.1016/j.chemosphere.2011.12.071.

122.Pérez-García, S.; Lubián, L. M.; Blasco, J.; Moreno-Garrido, I. Detection of intracellular Reactive Oxygen Species (ROS) by flow cytometry on microalgae: studies on laboratory monoalgal and natural mixed cultures., 2013, http://hdl.handle.net/10261/104150.

123. Kurade, M. B.; Kim, J. R.; Govindwar, S. P.; Jeon, B. H. Insights into microalgae mediated biodegradation of diazinon by Chlorella vulgaris: microalgal tolerance to xenobiotic pollutants and metabolism. Algal research 2016, 20, 126-134. https://doi.org/10.1016/j.algal.2016.10.003.

124.Zhang, W.; Jiang, F.; Ou, J. Global pesticide consumption and pollution: with China as a focus. Proceedings of the International Academy of Ecology and Environmental Sciences 2011, 1, 125.

125.Pérez-Legaspi, I. A.; Ortega-Clemente, L. A.; Moha-León, J. D.; Ríos-Leal, E.; Gutiérrez, S. C. R.; RubioFranchini, I. Effect of the pesticide lindane on the biomass of the microalgae Nannochloris oculata. Journal of Environmental Science and Health, Part B 2016, 51, 103-106. https://doi.org/10.1080/03601234.2015.1092824.

126. Ghasemi, Y.; Rasoul-Amini, S.; Fotooh-Abadi, E. The biotransformation, biodegradation, and bioremediation of organic compounds by microalgae 1. Journal of phycology 2011, 47, 969-980. https://doi.org/10.1111/j.1529-8817.2011.01051.x.

127.Kumar, A.; Singh, J. S. Cyanoremediation: a green-clean tool for decontamination of synthetic pesticides from agro-and aquatic ecosystems. Agro-environmental sustainability 2017, 59-83. https://doi.org/10.1007/978-3-319-49727-3_4.

128. Ortiz-Hernández, M. L.; Sánchez-Salinas, E.; Dantán-González, E.; Castrejón-Godínez, M. L. Pesticide biodegradation: mechanisms, genetics and strategies to enhance the process. Biodegradation-life of Science 2013, 251-287. https://doi.org/10.5772/56098.

129.Asad, M. A. U.; Lavoie, M.; Song, H.; Jin, Y.; Fu, Z.; Qian, H. Interaction of chiral herbicides with soil microorganisms, algae and vascular plants. Science of The Total Environment 2017, 580, 1287-1299. https://doi.org/10.1016/j.scitotenv.2016.12.092.

130. Yadav, H.; Kumar, R.; Sankhla, M. S. Residues of Pesticides and Heavy Metals in Crops Resulting in Toxic Effects on Living Organism. Journal of Seybold Repor 2020, https://doi.org/10.13140/RG.2.2.24806.65609.

131.Thakur, M.; Bajaal, S.; Rana, N.; Verma, M. L. Microalgal Technology: A Promising Tool for Wastewater Remediation. In Microbial Technology for Health and Environment, Springer, Singapore, 2020, pp. 25-56. https://doi.org/10.1007/978-981-15-2679-4_2.

132. Ghosh, A.; Kiran, B. Carbon concentration in algae: reducing CO2 from exhaust gas. Trends in biotechnology 2017, 35, 806-808. https://doi.org/10.1016/j.tibtech.2017.05.003.

133.Sagisaka, M. (Ed.). Sustainable Biomass Utilization Vision in East Asia. IDE-JETRO, 2008.

134.Gheewala, S. H.; Damen, B.; Shi, X. Biofuels: economic, environmental and social benefits and costs for developing countries in Asia. Wiley Interdisciplinary Reviews: Climate Change 2013, 4, 497-511. https://doi.org/10.1002/wcc.241. 
135.Bajwa, D. S.; Peterson, T.; Sharma, N.; Shojaeiarani, J.; Bajwa, S. G. A review of densified solid biomass for energy production. Renewable and Sustainable Energy Reviews 2018, 96, 296-305. https://doi.org/10.1016/j.rser.2018.07.040.

136. Acién Fernández, F. G.; Gómez-Serrano, C.; Fernández-Sevilla, J. M. Recovery of nutrients from wastewaters using microalgae. Front. Sustain. Food Syst. 2018, $2,59$. https://doi.org/10.3389/fsufs.2018.00059.

137.Gifuni, I.; Pollio, A.; Safi, C.; Marzocchella, A.; Olivieri, G. Current bottlenecks and challenges of the microalgal biorefinery. Trends in biotechnology 2019, $37, \quad 242-252$. https://doi.org/10.1016/j.tibtech.2018.09.006.

138. Gentili, F. G. Microalgal biomass and lipid production in mixed municipal, dairy, pulp and paper wastewater together with added flue gases. Bioresource technology 2014, 169, 27-32. https://doi.org/10.1016/j.biortech.2014.06.061.

139.Davis, R.; Aden, A.; Pienkos, P. T. Techno-economic analysis of autotrophic microalgae for fuel production. Applied Energy 2011, 88, 3524-3531. https://doi.org/10.1016/j.apenergy.2011.04.018.

140.Molinuevo-Salces, B.; Riaño, B.; Hernández, D.; García-González, M. C. Microalgae and wastewater treatment: advantages and disadvantages. In Microalgae biotechnology for development of biofuel and wastewater treatment, Springer, Singapore, 2019, 505-533.

141.Kumar, R.; Sankhla, M. S.; Kumar, R.; Sonone, S. S. Impact of Pesticide Toxicity in Aquatic Environment. Biointerface Research in Applied Chemistry, 2020, 11(3), 10131-10140. https://doi.org/10.33263/BRIAC113.1013110140.

142. Yadav, H.; Sankhla, M. S.; Kumar, R. Pesticides-induced carcinogenic \& neurotoxic effect on human. Forensic Res Criminol Int J 2019, 7, 243-245. 